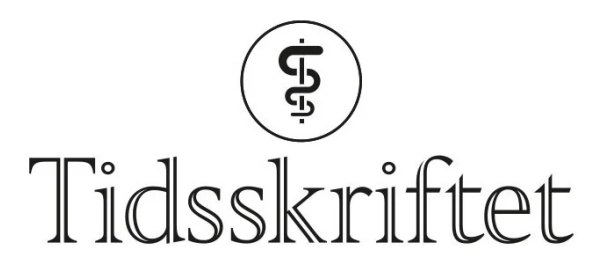

DEN NORSKE LEGEFORENING

\title{
Positronemisjonstomografi ved nevroendokrine svulster
}

OVERSIKTSARTIKKEL

\author{
MARTIN BIERMANN \\ Senter for nukleærmedisin/PET \\ Haukeland universitetssykehus \\ og \\ Institutt for kirurgiske fag \\ Universitetet i Bergen
}

\section{BOEL JOHNSEN}

Senter for nukleærmedisin/PET

\section{HALFDAN SøRBYE}

Kreftavdelingen

Senter for nukleærmedisin/PET

Haukeland universitetssykehus

\section{MAGNE FØLLING}

Senter for nukleærmedisin/PET

Haukeland universitetssykehus

\section{ANDERS SUNDIN}

Institutionen för Molekylär Medicin och Kirurgi Karolinska Universitetssjukhuset

Stockholm

\section{TORE BACH-GANSMO}

Email: ingolv.tore.bach-gansmo@helse-bergen.no

Senter for nukleærmedisin/PET

Haukeland universitetssykehus

5021 Bergen

og

Institutt for kirurgiske fag

Universitetet i Bergen

\section{BAKGRUNN.}

Nevroendokrine tumorer utgjør en liten gruppe maligne lidelser, med ca. 200 nye pasienter årlig i Norge. I denne artikkelen diskuteres problemene ved bruk av positronemisjonstomografi (PET) med fluorodeoksyglukose (FDG) ved disse tilstandene og hvilke andre muligheter som foreligger. Utfordringer ved introduksjonen av nye radiofarmaka i Norge blir også berørt.

\section{MATERIALE OG METODE.}

Artikkelen er basert på et ikke-systematisk litteratursøk i PubMed og gjennomgang av litteratur i forbindelse med utarbeiding av nye retningslinjer for nukleærmedisinske undersøkelser.

RESULTATER.

Nevroendokrine tumorer er i mange tilfeller langsomtvoksende, og nyere data viser at femårsoverlevelsen er ca. 50 \%. Et kjennetegn på nevroendokrine svulster er spesifikke biokjemiske prosesser. Det medfører muligheter for en rekke spesialtilpassede radiofarmaka for PET som vil kunne gjøre diagnose og oppfølging av disse pasientene langt mer sikker. 
Som for annen kreftsykdom er diagnostikk og påvisning av spredning en viktig faktor for riktig behandling av nevroendokrine tumorer. Bruk av FDG-PET ved slike tilstander har begrensninger. Nye, spesifikke radiofarmaka for PET kan føre til at nær 9o \% av alle slike tumorer kan påvises.

Nevroendokrine svulster er sjeldne, og det oppdages under 200 nye tilfeller årlig i Norge. I en nylig publisert oversiktsartikkel er det imidlertid beskrevet en $72 \% ø k n i n g$ i insidens i Norge fra perioden 1994-97 til perioden 2000-04 (1). Gjennomsnittlig overlevelse er fem år ved nevroendokrine svulster, men overlevelse kan være lang, selv ved metastatisk sykdom. Prevalensen av denne kreftformen er derfor høyere enn insidensraten skulle tilsi. Nevroendokrine svulster kan utvikles i en rekke anatomiske lokalisasjoner, og vanligst er karsinoider i tarmsystemet eller lungebronkier, mens en mindre andel utgjøres av endokrine pancreastumorer (1)-(4).

Kurativ behandling er, som for de fleste andre kreftformer, kirurgi. Der radikal kirurgi ikke er mulig, finnes det mange alternativer: medikamentell behandling (somatostatinanaloger, interferon), embolisering, kjemoterapi, stråleterapi og radioaktiv isotopbehandling. Som for annen kreft er diagnostikk og påvisning av mulig spredning en forutsetning for riktig behandling.

Nevroendokrine svulster kan påvises og til dels behandles med radiofarmaka som enten bindes til vevsspesifikke reseptorer eller inngår i en metabolsk prosess som er spesifikk for denne vevstypen. Standard utredning i dag innbærer derfor somatostatinreseptorscintigrafi, inklusive enfotonstomografi (single photon emission computed tomography, SPECT) med ${ }^{111}$ in-pentetreotid (octreoscan) for de fleste nevroendokrine svulster (5)-(.7.), eller ${ }^{123 / 131}$-metajodbenzylguanidin (MIBG)-scintigrafi ved tumorer utgående fra kromaffine celler og adrenergt nervevev, bl.a. feokromocytom og nevroblastom (5)-(.7). Metajodbenzylguanidin er en analog til adrenalin og akkumuleres i noradrenalinsekreterende celler. Ved siden av å være en sensitiv funksjonell diagnostisk metode for stadieinndeling av nevroendokrine svulster gir somatostatinreseptorscintigrafi ved høyt opptak indikasjon på at pasienten egner seg for farmakologisk behandling med somatostatinanaloger. Ved mer avansert sykdom utgjør tumoropptak ved somatostatinreseptorscintigrafi ett av kriteriene for å bestemme om pasienten vil ha nytte av isotopbehandling med radiofarmaka basert på somatostatinanaloger. Metoden gir også muligheter for å følge behandlingen, som derved kan individualiseres, slik at så stor dose radiofarmaka som mulig kan administreres uten å risikere skader på normalvev, som for eksempel nyrer.

Med en betydelig utvikling av positronemisjonstomografi de siste år er det kommet en rekke nye radiofarmaka for å påvise slike svulster. Ved PET benyttes radioaktive forbindelser basert på positronemisjon. Fordelene med PET er en oppløsningsevne på noen få millimeter, mot $\geq 1 \mathrm{~cm}$ for konvensjonell nukleærmedisin. Ved samtidig utført CT (PET-CT) får man i tillegg detaljert anatomisk informasjon. En helkroppsskanning tar 15-30 minutter med en moderne skanner. PET med ${ }^{18} \mathrm{~F}$-fluorodeoksyglukose (FDG) har i løpet av de siste årene blitt etablert som en rutinemodalitet for utredning av kreftpasienter $(\underline{8}, .9)$.

Et annet vesentlig moment er at det nå utvikles et bredt utvalg av spesifikke radiofarmaka for PET, til dels med bedre affinitet for målorganet enn de klassiske radiofarmaka ved enfotonstomografi (pentetreotid og MIBG), og da med de fysiske fordeler med PET som tilleggsgevinst. I tillegg til FDG-PET er det minst sju forskjellige preparater for PET på trappene. Preparater som ${ }^{68} \mathrm{Ga}$-DOTATOC, ${ }^{68} \mathrm{Ga}$-DOTANOC,,${ }^{11} \mathrm{C}$-5-hydroksytryptofan, ${ }^{18} \mathrm{~F}$ DOPA, ${ }^{11} \mathrm{C}$-hydroksyefedrin, og ${ }^{18} \mathrm{~F}$-dopamin er i regelmessig bruk i denne pasientkategorien $(\underline{6}, \underline{10})-(\underline{21})$, samtidig som ${ }^{11} \mathrm{C}$-metomidat har vist seg verdifull ved binyrebarksvulster hvor CT og MR ikke er tilstrekkelig for diagnose

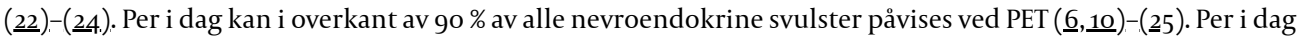
utføres kun FDG-PET i Norge, men vi håper at PET med noen av disse nye radiofarmaka kommer i løpet av 2009. Målet med denne artikkelen er å formidle informasjon om begrensningene ved PET med fluorodeoksyglukose ved disse tilstandene samt informere om de mange nye radiofarmaka for PET som er under introduksjon.

\section{Materiale og metode}

Artikkelen er basert på et ikke-systematisk litteratursøk i PubMed i forbindelse med utarbeiding av nye retningslinjer for nukleærmedisinske undersøkelser for å oppdatere Veileder for diagnostikk og behandling av

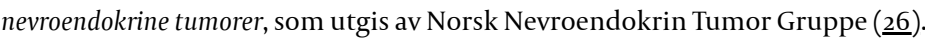

\section{PET-radiofarmaka ved nevroendokrine svulster}

\section{F-FLOURODEOKSYGLUKOSE}

PET med ${ }^{18} \mathrm{~F}$-flourodeoksyglukose $\left({ }^{18} \mathrm{~F}\right.$-FDG) er en utmerket nukleærmedisinsk metode for å påvise tumorer med $\emptyset \mathrm{kt}$ glukosemetabolisme, som f.eks. plateepitelkarsinomer (hode/hals, oesophagus), lungecancer, coloncancer, lymfomer og melanomer $(\underline{8}$, .9.). Nevroendokrine svulster skiller seg imidlertid fra mange andre krefttyper ved at de fleste er høyt differensierte med langsom proliferasjon og lav glukoseomsetning, og vil ved FDG-PET gi falskt negativt svar $(5)-(7, \underline{14}, \underline{16}, \underline{2} 7$.$) . Imidlertid kan nevroendokrine svulster dedifferensiere, glukosemetabolismen$ oppreguleres og tumoren bli påvisbar med FDG-PET $(5,7, \underline{14}, \underline{21})$. Høy glukoseomsetning oppfattes som et tegn på 
aggressiv tumor $(\underline{6}, \underline{21}, \underline{27}$.$) . Fluorodeoksyglukose er dessuten anvendelig til karakterisering av maligne$ binyresvulster som først er påvist ved CT eller $\mathrm{MR}(\underline{\mathbf{2} 8}, \mathbf{2 9})$.). Ved pågående behandling med kjemoterapi vil redusert celledeling og glukosemetabolisme kunne gi falskt negative svar i flere uker etter en behandling.

\section{SOMATOSTATINRESEPTOR}

De fleste nevroendokrine svulster uttrykker somatostatinreseptorer og kan derfor påvises ved hjelp av forbindelser som har høy affinitet for slike reseptorer. ${ }^{68}$ Gallium-DOTATOC er et legemiddel med høy affinitet til undertype 2 av disse reseptorene $(5, \underline{6}, \underline{10}, \underline{11})$. I forhold til konvensjonell scintigrafi er fordelene med ${ }^{68} \mathrm{Ga}$ DOTATOC-PET at helkroppsavbilding kan utføres på mindre enn 30 minutter en time etter injeksjon og at kostnadene per undersøkelse er relativt lave. Produktet er ikke avhengig av syklotron, fordi ${ }^{68} \mathrm{Ga}$ kan ekstraheres daglig fra en generator som varer ca. ett år. Ved konvensjonell nukleærmedisin benyttes ${ }^{111}$ In-pentetreotid.

Da kreves bildetaking fire og 24 timer etter injeksjon, av og til også etter 48 timer. I tillegg tar avbilding 11/2 time dersom man ønsker enfotonstomografi av både thorax og abdomen $(5, \underline{6}) .{ }^{68} \mathrm{Ga}$-DOTANOC er et liknende oligopeptid, men med høy affinitet for både somatostatinreseptor 2 og 5 . Denne er angitt å gi enda bedre kontrast $(\underline{11}, \underline{12}) .{ }^{68} \mathrm{Ga}$-DOTATOC og ${ }^{68} \mathrm{Ga}$-DOTANOC er hovedsakelig indisert ved feokromocytom, karsinoide svulster og nevroendokrine pancreastumorer som f.eks. insulinomer. Hos pasienter med nevroendokrine svulster ble det $\mathrm{i}$ en nylig studie vist en sensitivitet for CT på $61 \%$, for ${ }^{111}$ In-pentetreotid på $52 \%$ og for ${ }^{68}$ Ga-DOTATOC-PET på $97 \%$.

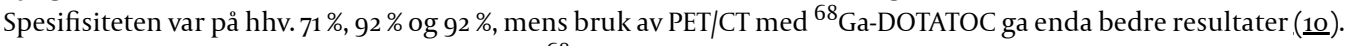
Som for somatostatinreseptorscintigrafi viser ${ }^{68} \mathrm{Ga}$-DOTATOC-PET om slike svulster er egnet for behandling med ${ }^{90}$ ytrium eller ${ }^{177}$ lutetium-DOTANOC eller ${ }^{177}$ lutetium-DOTATOC $(\underline{6}, \underline{12})$. Omkostningene ved å etablere ${ }^{68} \mathrm{Ga}$ DOTATOC ved et eksisterende PET-senter vil ligge på ca. 500 ooo kr. Ved et minimum på 70 undersøkelser per år vil kostnadene bli sammenliknbare med utgiftene for ${ }^{111}$ In-pentetreotid-scintigrafi.

\section{APUD-AVHENGIGE RADIOFARMAKA}

Apudomer eller svulster som karakteriseres ved opptak og dekarboksylering av aminosyrer, kan fremstilles ved radiofarmaka basert på aminosyrene tryptofan og fenylalanin, hhv. 5-hydroksy-L-tryptofan (5-HTP) og hydroksyfenylalanin. Disse tas opp i apudomer og konverteres til respektive serotonin og dopamin og lagres i sekretoriske granuler i cytoplasma i for eksempel karsinoide og endokrine pancreastumorer (gastrinomer, insulinomer, glukagonomer).

${ }^{11}$ C-HYDROKSYTRYPTOFAN

${ }^{11} \mathrm{C}$-hydroksytryptofan $\left({ }^{11} \mathrm{C}-5\right.$-HPT $)$ er et radiofarmakon utviklet ved Universitetet i Uppsala. ${ }^{11} \mathrm{C}-5$-HTP akkumuleres spesifikt i svulster som produserer eller kan produsere serotonin (13)-(17.). ${ }^{11} \mathrm{C}-5$-HTP-PET viser derfor høyt opptak i en rekke forskjellige nevroendokrine svulster som f.eks. de karsinoide (fig 1 ), øycellepancreastumorer, men også ikke-funksjonelle endokrine pancreastumorer (13). ${ }^{11} \mathrm{C}-5$-HPT-PET er bedre enn CT, somatostatinreseptorscintigrafi og er også rapportert bedre enn ${ }^{18} \mathrm{~F}$-DOPA-PET for nevroendokrine svulster i pancreas. Spesielt kan relativt små lesjoner påvises $(\underline{14}, \underline{15})$. Undersøkelsen er mest relevant for å kartlegge usikre lesjoner ved planlagt kurativ metastasekirurgi og ved utredning av suspekt klinisk residiv som ikke lar seg påvise med CT og scintigrafi. Ytterligere indikasjon for ${ }^{11} \mathrm{C}-5$-HPT-PET er oppfølging av behandling når resultatene av radiologiske, biokjemiske og kliniske undersøkelser divergerer.

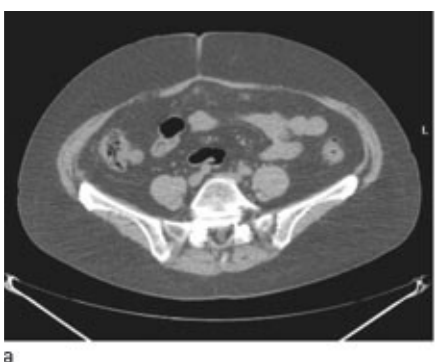

Figur 1 HTP-PET. a) PET, b) Lavdose CT, c) Fusjonert PET/CT. Pasient operert for tynntarmskarsinoid med
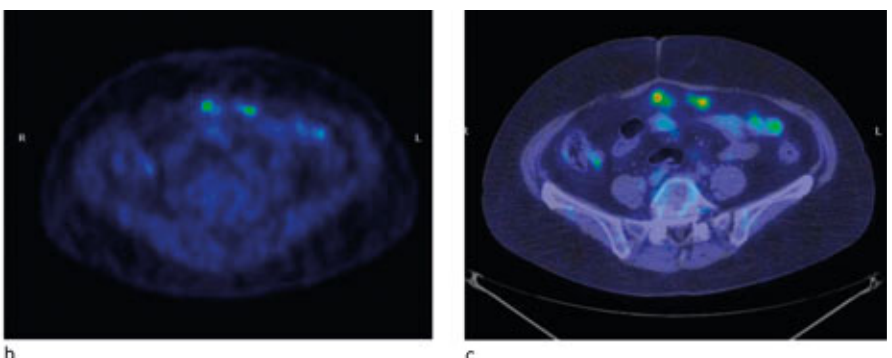

biokjemiske holdepunkter for residiv. Opptak av 5-hydroksytryptofan (HTP) i to små mesenterielle lymfekutemetastaser fortil i buken. Til venstre i bildet ses et svakt fysiologisk HTP-opptak i tynntarm ${ }^{18} \mathrm{~F}$-DOPA

På samme vis som ${ }^{11} \mathrm{C}-5$-HPT har ${ }^{18} \mathrm{~F}$-DOPA vist gode resultater ved påvisning av nevroendokrine svulster $(5, \underline{6}, \underline{15})$ (17.). F-DOPA er også i utstrakt bruk i Europa, i motsetning til ${ }^{11} \mathrm{C}-5-\mathrm{HTP}$, som bare få sentre benytter. For å påvise medullær thyreoideacancer har F-DOPA-PET vist seg å være bedre enn FDG-PET eller ${ }^{111}$ In-pentetreotid (17.). FDOPA-PET/CT er også beskrevet som den optimale undersøkelsen for pasienter med karsinoide tumorer, også bedre enn ${ }^{11} \mathrm{C}$-5-HPT-PET (17.).

\section{Andre PET-radiofarmaka ved endokrine svulster}

\section{${ }^{11}$ C-META-HYDROKSYEFEDRIN}

En positronemitterende substans som gir tilsvarende bildeinformasjon som MIBG-scintigrafi, men bedre oppløsning er ${ }^{11} \mathrm{C}$-hydroksyefedrin $\left({ }^{11} \mathrm{C}-\mathrm{HED}\right)(\underline{18}, 19)$. Metoden kan brukes ved mistanke om tumorer fra det sympatiske nervesystemet (feokromocytom, paragangliom, nevroblastom). Det anbefales å seponere en rekke farmaka før undersøkelsen. Opptak er fysiologisk i lever og i alle organer med sympatisk innervasjon (spyttkjertler, hjerte), og stoffet utskilles via nyrene. Fokalt opptak utenfor disse organene er tumorsuspekt, med 
en sensitivitet på $90 \%$ og en spesifisitet på nesten $100 \%(19$.$) . Fokalt opptak i en binyre etablerer diagnosen$ feokromocytom (fig 2). I en studie med ${ }^{11} \mathrm{C}$-HED-PET hos 12 pasienter med 13 feokromocytomer viste metoden $92 \%$ sensitivitet og $100 \%$ spesifisitet (19).

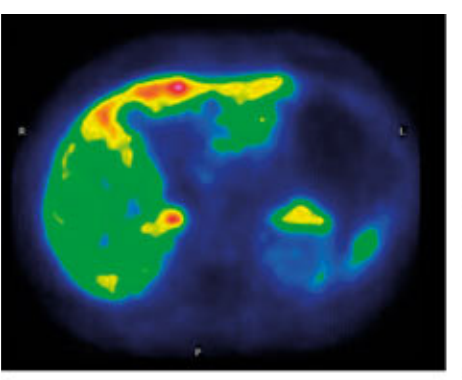

Figur 2 HED-PET. a) PET, b) Lavdose CT, c) Fusjonert PET/CT. Pasient med symptomer og biokjemiske holdepunkter for feokromocytom. HED-PET viser opptak i feokromocytom i høyre binyre. Fysiologisk opptak av 11Chydroksyefedrin (HED) (til venstre i bildet)i pancreashalen og i lever $6-\left({ }^{18} \mathrm{~F}\right)$ DOPAMIN

Enda et radiofarmakon som er under utprøvning hos pasienter med feokromocytom er $6-\left({ }^{18} \mathrm{~F}\right)$ dopamin $\left({ }^{18} \mathrm{~F}-\mathrm{DA}\right)$ $(\underline{20}, \underline{21})$. Hypotesen er at en lav ekspresjon av norepinefrintransportersystem ved feokromocytom som ledd i von Hippel-Lindaus sykdom er ansvarlig for redusert opptak ved MIBG-scintigrafi. ${ }^{18} \mathrm{~F}$-DA har vist gode resultater hos slike pasienter, med meget høy sensitivitet og spesifisitet i små serier. Men også blant slike pasienter kan

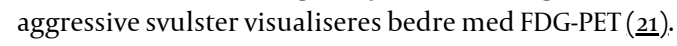

${ }^{11}$ C-METOMIDAT

Metomidat er en ${ }^{11} \mathrm{C}$-merket enzymhemmer som blokkerer enzymet 11-betahydroksylase, et essensielt enzym i produksjonen av kortisol og aldosteron. For diagnostisk avklaring ved binyresvulster og binyrebarkkreft kan PET med ${ }^{11} \mathrm{C}$-metomidat anvendes når verken $\mathrm{CT}$ eller MR er tilstrekkelig for diagnostikk. Metomidat er blitt brukt til

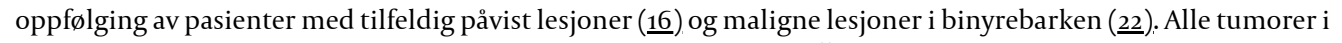
binyrebarken, også binyrebarkcancer har vist meget høyt opptak av ${ }^{11} \mathrm{C}$-metomidat, og høyt opptak plasserer

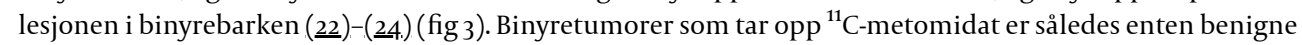

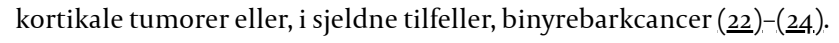
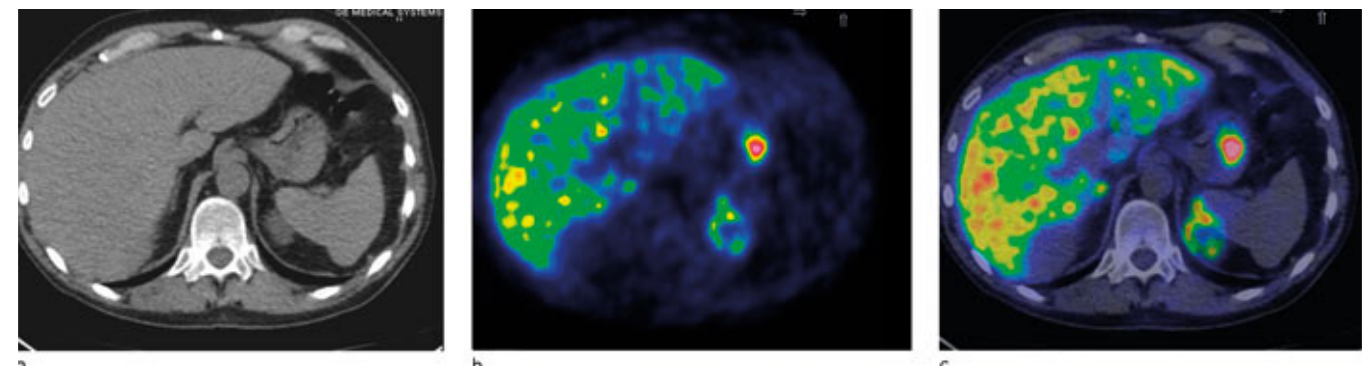
b

Figur 3 Metomidat-PET. a) PET, b) Lavdose CT, c) Fusjonert PET/CT. Pasient henvist for generell sykdomsfølelse. Ved CT ble det påvist en venstresidig binyretumor. Videre utredning med metomidat-PET pga. mistanke om binyrebarkcancer (adrenokortikalt karsinom). Karakteristiske funn som viser perifert opptak i en for øvrig nekrotisk primærtumor samt påvist metastase (ikke på bildet). Det høye metomidatopptaket til venstre i bildet er i magesaft i ventrikkelen, et karakteristisk, fysiologisk funn ved metomidat

\section{Utfordringer}

\section{OPPLARING OG FORMIDLING AV KUNNSKAP}

Klinikere må kjenne til PET og metodens begrensninger. En kliniker som henviser en pasient til PET-skanning, har også ansvar for å ha nok kunnskap til å kunne gi en korrekt klinisk fortolkning. Kliniker og nukleærmedisiner må kjenne til betydningen av valg av radiofarmaka i forhold til tumortype. Dersom ikke disse kunnskapene er på plass, kan diagnostikk og behandling lett bli langt dårligere enn det dagens teknologi tillater. Spesielt er det viktig å kjenne begrensningene ved FDG-PET, og at det finnes alternativer.

UTVIKLING OG VALG AV RADIOFARMAKA

I utgangspunktet er det høye antallet nye radiofarmaka et tveegget sverd. Problemstillingen rundt bruk av nye radiofarmaka for PET er blitt en hodepine både for norsk og europeisk nukleærmedisin (225). Fra Haukeland universitetssykehus ble det sendt fem pasienter til utlandet i 2007, tre for F-DOPA-PET (hvorav én for hyperinsulinisme) og to til 5-HTP-PET, men det er trolig mange flere som ville hatt stor nytte av slike unders $\emptyset$ kelser selv om det ikke er på vital indikasjon (25). Det foreligger en rekke kliniske publikasjoner som tyder på høy diagnostisk nytteverdi for de beskrevne radiofarmaka $(5)-(7, \underline{10})-(\underline{24})$.). De fleste produktene er ti år gamle eller mer, ikke patenterbare, er for små pasientgrupper - og derfor av liten interesse for farmasøytisk industri. Det vil være en svært ressurskrevende oppgave for en opptatt sykehusavdeling å fremlegge et fullt dossier for et slikt nytt legemiddel, og tilnærmet umulig for sju nye radiofarmaka. Det er derfor knyttet en viss 
spenning til hvordan Legemiddelverket vil regulere bruken av disse legemidlene i Norge. Det er imidlertid sannsynlig at Ga-DOTATOC vil bli tilbudt pasienter ved både Rikshospitalet og Haukland universitetssykehus i løpet av 2009, som det første av alle disse nye legemidlene.

\section{Tabell 1}

De hyppigste nevroendokrine tumorer og PET-radiofarmaka til påvisning av disse.+|++|+++= indikasjon, $(++)=$ sannsynlig men ikke veldokumentert indikasjon

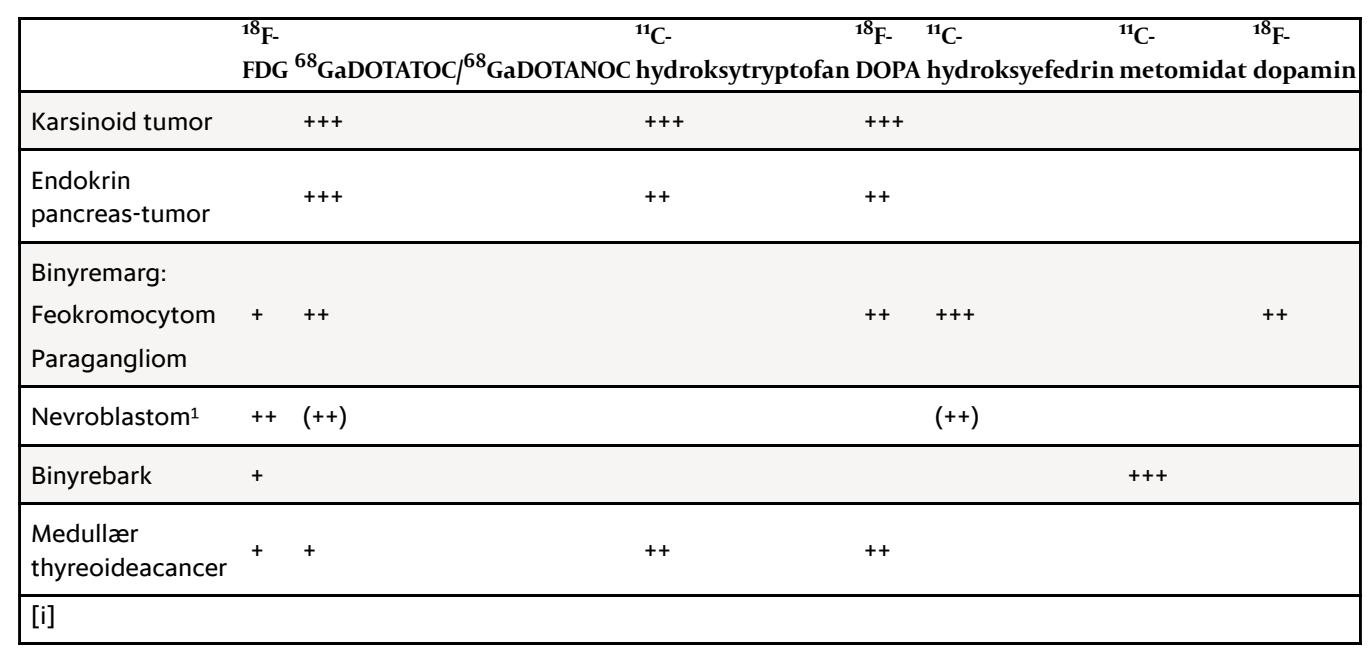

[i] ${ }^{1}$ For nevroblastomer foreligger det ikke god dokumentasjon. FDG-PET er indisert ved MIBG-negative svulster, ${ }^{68} \mathrm{GaDOTATOC} /{ }^{68} \mathrm{GaDOTANOC}$ og ${ }^{11} \mathrm{C}$-hydroksyefedrin har vist opptak, men gode, systematiske studier er ikke publisert

\section{Konklusjon}

Det et utstrakt bruk av andre radiofarmaka enn fluorodeoksyglukose ved nevroendokrine svulster. Per i dag er anvendelsesområdet for hvert enkelt preparat definert av hvilket radiofarmakon det enkelte senter disponerer, og det er stadig ikke veldokumentert hvilket legemiddel som skal benyttes ved en gitt tumortype. Klinikere bør imidlertid kjenne til begrensningene ved PET og hvordan cancertype og valg av radiofarmaka kan influere på resultatet. Det er et stort behov for en nasjonal planlegging av hvilke legemidler som bør inngå i den kliniske hverdag ved landets PET-sentre.

Statens legemiddelverk eller European Medicines Agency bør kunne tilkjennegi på et nettsted, gjerne på forespørsel fra klinisk hold, at for et gitt radiofarmakon foreligger det tilstrekkelig dokumentasjon slik at ytterligere toksikologisk eller annen utredning ikke er nødvendig. Da ville ikke hver avdeling som $ø$ nsker å benytte disse nye radiofarmaka, måtte sette sammen en slik dokumentasjon. Man ville også legge forholdene til rette for $\emptyset$ kt og riktig bruk av disse legemidlene der det ikke finnes farmasøytisk industriell interesse for å drive frem registrering.

\section{Oppgitte interessekonflikter:}

Ingen

Tabell

\begin{tabular}{|l|}
\hline Hovedbudskap \\
\hline - $\quad$ FDG-PET har begrensninger ved nevroendokrine tumorer \\
tumorer påvises \\
- Det er ikke sikker dokumentasjon for hvilket preparat som er best ved en gitt tumortype \\
- Introduksjon av disse og andre radiofarmaka i Norge er avhengig av en ny tilnærming til dokumentasjonskrav
\end{tabular}


1. Hauso $\emptyset$, Gustafsson BI, Kidd M et al. Neuroendocrine tumor epidemiology contrasting Norway and North America. Cancer 2008; $113: 2655-64$.

2. Husebye E, Varhaug J, Heimdal K. Arvelige endokrine tumorsykdommer Tidsskr Nor Lægeforen 2005; 125: 2964-7.

3. Perez EA, Koniaris LG, Snell SE et al. 7201 carcinoids: increasing incidence overall and disproportionate mortality in the elderly. World J Surg 2007; 31:1022-30.

4. Bilimoria KY, Tomlinson JS, Merkow RP et al. Clinicopathologic features and treatment trends of pancreatic neuroendocrine tumors: analysis of 9,821 patients. J Gastrointest Surg 2007; 11: 1460-7.

5. Biermann M. Nukleærmedisin ved Universitet i Bergen. www.med.uib.no/radioweb/nuklear/ (23.4.2009).

6. Rufini V, Calcagni ML, Baum RP. Imaging of neuroendocrine tumors. Semin Nucl Med 2006; 36: 228-47.

7. Bombardieri E, Maccauro M, De Deckere E et al. Nuclear medicine imaging of neuroendocrine tumours. Ann Oncol $2001 ; 12$ (suppl 2): S51-61.

8. Fletcher JW, Djulbegovic B, Soares HP et al. Recommendations on the use of 18F-FDG PET in oncology. J Nucl Med 2008; 49 : $480-508$.

9. Hillner BE, Siegel BA, Liu D et al. Impact of positron emission tomography/computed tomography and positron emission tomography (PET) alone on expected management of patients with cancer: Initial results from the national oncologic PET registry. J Clin Oncol 2008; 26: 2155-61.

10. Gabriel M, Decristoforo C, Kendler D et al. 68Ga-DOTA-Tyrz-octreotide PET in neuroendocrine tumors: comparison with somatostatin receptor scintigraphy and CT. J Nucl Med 2007; 48: 508-18.

11. Pettinato C, Sarnelli A, Di Donna M et al. (68)Ga-DOTANOC: biodistribution and dosimetry in patients affected by neuroendocrine tumors. Eur J Nucl Med Mol Imaging 2008; 35: 72-9.

12. Wild D, Macke HR, Waser B et al. 68Ga-DOTANOC: a first compound for PET imaging with high affinity for somatostatin receptor subtypes 2 and 5. Eur J Nucl Med Mol Imaging 2005; 32: 724.

13. Örlefors H, Sundin A, Garske U et al. Whole-body (11)C-5-hydroxytryptophan positron emission tomography as a universal imaging technique for neuroendocrine tumors: comparison with somatostatin receptor scintigraphy and computed tomography. J Clin Endocrinol Metab 2005; 90:3392-4000.

14. Sundin A, Eriksson B, Bergström M et al. PET in the diagnosis of neuroendocrine tumors. Ann N Y Acad Sci 2004; 1014: 24657 .

15. Koopmans KP, Neels OC, Kema IP et al.. Improved staging of patients with carcinoid and islet cell tumors with $18 \mathrm{~F}$ dihydroxy-phenyl-alanine and 11C-5-hydroxy-tryptophan positron emission tomography. J Clin Oncol 2008; 26: 1489-95.

16. Eriksson B, Bergström M, Sundin A et al. The role of PET in localization of neuroendocrine and adrenocortical tumors. Ann N Y Acad Sci 2002; 970: 159-69.

17. Hoegerle S, Altehoefer C, Ghanem N et al. 18F-DOPA positron emission tomography for tumour detection in patients with medullary thyroid carcinoma and elevated calcitonin levels. Eur J Nucl Med 2001; 28: 64-71.

18. Franzius C, Hermann K, Weckesser M et al. Whole-body PET/CT with 11C-meta-hydroxyephedrine in tumors of the sympathetic nervous system: feasibility study and comparison with 123I-MIBG SPECT/CT. J Nucl Med 2006; 47: 1635-42.

19. Trampal C, Engler H, Juhlin C et al. Pheochromocytomas: detection with 11C hydroxyephedrine PET. Radiology 2004; 230: $423-8$.

20. Ilias I, Yu J, Carrasquillo JA et al. Superiority of 6-[18F]-fluorodopamine positron emission tomography versus [131I]metaiodobenzylguanidine scintigraphy in the localization of metastatic pheochromocytoma. J Clin Endocrinol Metab 2003; 88: $4083-7$.

21. Mamede M, Carrasquillo JA, Chen CC et al. Discordant localization of 2-[18F]-fluoro-2-deoxy-D-glucose in 6-[18F]fluorodopamine- and [(123)I]-metaiodobenzylguanidine-negative metastatic pheochromocytoma sites. Nucl Med Commun 2006; 27:31-6.

22. Khan TS, Sundin A, Juhlin C et al. 11C-metomidate-PET imaging of adrenocortical cancer. Eur J Nucl Med Mol Imaging 2003; 30: 403-10.

23. Hennings J, Lindhe $\mathrm{O}$, Bergström M et al. [11C]metomidate positron emission tomography of adrenocortical tumors in correlation with histopathological findings. J Clin Endocrinol Metab 2006; 91: 1410-4.

24. Hennings J, Hellman P, Ahlström $\mathrm{H}$ et al. Computed tomography, magnetic resonance imaging and $11 \mathrm{C}$-metomidate positron emission tomography for evaluation of adrenal incidentalomas. Eur J Radiol 2007;34: 978-82.

25. Breeman WAP, Verbruggen AM. The 68Ge/68Ga generator has high potential, but when can we use 68Ga-labelled tracers in clinical routine? Eur J Nucl Med Mol Imaging 2007;34: 978-81.

26. Falkmer U, Husebye E, red. Neuroendokrine tumorer. En veiledning til diagnostikk og behandling. 2. utg. Oslo: Norsk Neuroendokrin Tumor Gruppe og Den Norske Kreftforening, 2003.

27. Adams S, Baum R, Rink T et al. Limited value of fluorine-18 fluorodeoxyglucose positron emission tomography for the imaging of neuroendocrine tumours. Eur J Nucl Med 1998; 25: 79-83.

28. Yun M, Kim W, Alnafisi N et al. 18F-FDG PET in characterizing adrenal lesions detected on CT or MRI. J Nucl Med 2001; 42: 1795-9.

29. Boland GWL, Blake MA, Holalkere NS et al. PET/CT for the characterization of adrenal masses in patients with cancer: qualitative versus quantitative accuracy in 150 consecutive patients. AJR Am J Roentgenol 2009; 192: 956-62.

Publisert: 13. august 2009. Tidsskr Nor Legeforen. DOI: 10.4045/tidsskr.o8.0o68

Manuskriptet ble mottatt 14.7. 2008 og godkjent 23.4. 2009. Medisinsk redaktør Trine B. Haugen.

(C) Tidsskrift for Den norske legeforening 2023. Lastet ned fra tidsskriftet.no 26. april 2023. 